\title{
Meiothermus hypogaeus sp. nov., a moderately thermophilic bacterium isolated from a hot spring
}

\author{
Correspondence \\ Koji Mori \\ mori-koji@nite.go.jp
}

\author{
Koji Mori, ${ }^{1}$ Takao lino, ${ }^{1}$ Jun-ichiro Ishibashi, ${ }^{2}$ Hiroyuki Kimura, ${ }^{3}$ \\ Moriyuki Hamada ${ }^{1}$ and Ken-ichiro Suzuki ${ }^{1}$
}
${ }^{1}$ NITE Biological Resource Center (NBRC), National Institute of Technology and Evaluation (NITE), 2-5-8 Kazusakamatari, Kisarazu, Chiba 292-0818, Japan
${ }^{2}$ Faculty of Science, Kyushu University, Higashi-ku, Fukuoka 812-8581, Japan
${ }^{3}$ Faculty of Science, Shizuoka University, 836 Oya, Suruga-ku, Shizuoka 422-8529, Japan

\begin{abstract}
A novel moderately thermophilic, red-pigmented bacterium, designated strain $A Z M 34 \mathrm{c} 11^{\top}$, was isolated from the bottom of a $1000 \mathrm{~m}$-deep drilled well located in a Japanese hot spring. Cells were Gram-negative and grew optimally at $50{ }^{\circ} \mathrm{C}$, at $\mathrm{pH} 7.6$ and with $0-0.3 \%(\mathrm{w} / \mathrm{v}) \mathrm{NaCl}$. Analysis of the 16S rRNA gene sequence revealed that the isolate belonged to the genus Meiothermus. Levels of $16 \mathrm{~S}$ rRNA gene sequence similarity between strain $A Z M 34 \mathrm{c} 11^{\top}$ and the type strains of recognized Meiothermus species were $88.2-94.8 \%$. Strain AZM34c11 ${ }^{\top}$ was distinguished from recognized Meiothermus species by its cellular fatty acid profile: iso- $\mathrm{C}_{16: 0}$ was one of the predominant components and hydroxy fatty acids were present only in trace amounts. The strain could also be differentiated based on its growth substrate preferences and characteristic enzyme reactions. On the basis of these results, strain $A Z M 34 c 11^{\top}$ is considered to represent a novel species of the genus Meiothermus, for which the name Meiothermus hypogaeus sp. nov. is proposed. The type strain is AZM34c11 ${ }^{\top}\left(=\mathrm{NBRC} 106114^{\top}=\mathrm{DSM}\right.$ $\left.23238^{\top}\right)$.
\end{abstract}

The genus Meiothermus comprises strictly aerobic, nonhalophilic and moderately thermophilic heterotrophs. The first species to be described was Meiothermus ruber, isolated from the Kamchatka Peninsula (Loginova et al., 1984). M. ruber, Meiothermus silvanus and Meiothermus chliarophilus were originally described as members of the genus Thermus (Tenreiro et al., 1995). However, based on differences in optimal growth temperature range, 2-hydroxy fatty acid content and 16S rRNA gene sequences, they were later reclassified within a separate genus (Nobre et al., 1996). At the time of writing, the genus Meiothermus comprises nine recognized species (Albuquerque et al., 2009, 2010; Chen et al., 2002; Chung et al., 1997; Pires et al., 2005; Zhang et al., 2010). Many strains belonging to the genus Meiothermus have been isolated from various natural geothermal samples as well as from man-made environments (Ekman et al., 2007). The phenotypic diversity has gradually increased with the description of additional isolates of the genus Meiothermus: Meiothermus cerbereus

Abbreviations: $\mathrm{ML}$, maximum-likelihood; $\mathrm{NJ}$, neighbour-joining.

The GenBank/EMBL/DDBJ accession numbers for the 16S rRNA gene sequences of strain AZM34c1 $11^{\top}$ and Meiothermus taiwanensis NBRC $105868^{\top}$ (A and B genes) are AB586707, AB586708 and AB586709, respectively.

A supplementary table is available with the online version of this paper. and some strains of $M$. silvanus require reduced sulfur compounds for growth in liquid medium (Chung et al., 1997; Nobre \& da Costa, 2001), Meiothermus rufus and Meiothermus granaticius lack cellular hydroxy fatty acids, which are present in other species (Albuquerque et al., 2009, 2010), and M. chliarophilus and Meiothermus timidus form yellow-pigmented colonies, whereas other species form redpigmented colonies (Pires et al., 2005; Tenreiro et al., 1995). With regard to $16 \mathrm{~S}$ rRNA gene sequence divergence, phylogenetic analyses indicated that $M$. silvanus, $M$. chliarophilus and M. timidus are distantly related to other species of the genus, including the type species $M$. ruber. This might suggest placing them in a separate genus, but there are no suitable phenotypic differences to separate the two groups (Nobre \& da Costa, 2001; Nobre et al., 1996).

We isolated a novel moderately thermophilic, aerobic, Meiothermus-like bacterium from a water sample collected from the bottom of a 1000 m-deep drilled well in HakubaHimekawa hot spring located in Nagano Prefecture, Japan. The water sample was collected on the surface in June 2008 and its temperature and $\mathrm{pH}$ were $48{ }^{\circ} \mathrm{C}$ and 7.5. To enrich and isolate bacteria, we used AP13YO liquid medium (approx. pH 7), i.e. AP13 basal medium supplemented with (per litre) $0.1 \mathrm{~g}$ Bacto yeast extract (Difco) under a $\mathrm{N}_{2} / \mathrm{CO}_{2} / \mathrm{O}_{2}[70: 20: 10(\mathrm{v} / \mathrm{v}) ; 150 \mathrm{kPa}]$ atmosphere. AP13 basal medium had the following composition (per litre): 
$0.05 \mathrm{~g} \mathrm{~K}_{2} \mathrm{HPO}_{4}, 0.09 \mathrm{~g} \mathrm{KH}_{2} \mathrm{PO}_{4}, 0.25 \mathrm{~g} \mathrm{MgSO}_{4} .7 \mathrm{H}_{2} \mathrm{O}$, $0.15 \mathrm{~g} \mathrm{CaCl} 2.2 \mathrm{H}_{2} \mathrm{O}, 0.25 \mathrm{~g} \mathrm{NH}_{4} \mathrm{Cl}, 1 \mathrm{ml}$ trace element solution (Mori et al., 2008a) and $0.25 \mathrm{~g} \mathrm{Na}_{2} \mathrm{CO}_{3}$. The medium was prepared in serum bottles with butyl-rubber stoppers and aluminium caps under $\mathrm{N}_{2} / \mathrm{CO}_{2} / \mathrm{O}_{2}$ and then autoclaved. For enrichment and routine cultivation, $50 \mathrm{ml}$ serum bottles containing $20 \mathrm{ml}$ liquid medium were used. For primary enrichment of bacteria, $1 \mathrm{ml}$ hot-spring water was inoculated into $20 \mathrm{ml}$ AP13YO medium and incubated at $50{ }^{\circ} \mathrm{C}$. After 1 week of incubation, bacterial growth was confirmed by microscopy and the enrichment culture was repeatedly transferred to fresh AP13YO medium. For single strain isolation, colonies were allowed to form on Gelrite plates prepared with the same medium amended with $1 \mathrm{~g} \mathrm{MgCl}_{2} \cdot 6 \mathrm{H}_{2} \mathrm{O} \mathrm{l}^{-1}$ and $0.6 \%$ (w/v) gellan gum. After 1 week, uniform red colonies (approx. $0.5 \mathrm{~mm}$ in diameter) were observed and a single colony was picked and purified by repeating the isolation procedure several times. Strain AZM $34 \mathrm{c} 11^{\mathrm{T}}$ was isolated successfully from the enriched sample. After the isolation procedure, we tested the growth of strain AZM34c11 ${ }^{\mathrm{T}}$ on Thermus medium (Castenholz, 1969) supplemented with (per litre) $1 \mathrm{~g}$ Bacto yeast extract, $1 \mathrm{~g}$ Bacto tryptone (Difco) and $1 \mathrm{~g}$ sodium glutamate to raise the growth yield, and found positive results: red colonies formed on this agar plate after 1 week of incubation at $50{ }^{\circ} \mathrm{C}$.

Cells of strain AZM34c11 ${ }^{\mathrm{T}}$ were Gram-negative rods (0.4 $\mu \mathrm{m}$ wide and $1.7-10.0 \mu \mathrm{m}$ long). Spore formation and motility were not observed. Cells were catalasenegative and oxidase-positive (Tamaki et al., 2003).

Strain AZM34c11 ${ }^{\mathrm{T}}$ was unable to grow in the presence of nitrate $(10 \mathrm{mM})$, nitrite $(2$ and $5 \mathrm{mM})$, fumarate $(10 \mathrm{mM})$, thiosulfate $(10 \mathrm{mM})$, sulfate $(10 \mathrm{mM})$, sulfite $(2$ and $5 \mathrm{mM})$ or elemental sulfur $(2 \%)$ as an elemental acceptor in the AP13 medium with (per litre) $0.1 \mathrm{~g}$ Bacto yeast extract and $3.4 \mathrm{~g}$ sucrose under $\mathrm{N}_{2} / \mathrm{CO}_{2}[80: 20(\mathrm{v} / \mathrm{v}) ; 150 \mathrm{kPa}]$. Accordingly, strain AZM $34 \mathrm{c} 11^{\mathrm{T}}$ was considered to be strictly aerobic, and neither fermentative growth nor respiration was observed under anaerobic conditions. Nitrate was reduced to nitrite (Dobrogosz, 1981), although no cell growth occurred. A reduced sulfur compound (thiosulfate) was not required for growth of strain AZM $34 \mathrm{c} 11^{\mathrm{T}}$ in the liquid medium. Yeast extract $\left(0.1 \mathrm{~g} \mathrm{l}^{-1}\right)$ was necessary for growth. Strain AZM $34 \mathrm{c} 11^{\mathrm{T}}$ utilized several single carbon sources for growth (Table 1). The optimum temperature, $\mathrm{pH}$ and $\mathrm{NaCl}$ concentration ranges for growth in Thermus medium with (per litre) $1 \mathrm{~g}$ Bacto yeast extract, $1 \mathrm{~g}$ Bacto tryptone and $3.4 \mathrm{~g}$ sucrose were determined by examining the time course of optical density (temperature gradient incubator with a bio-photorecorder, model TN-2612; ADVANTEC). The experiments were performed in duplicate. Strain AZM $34 \mathrm{c} 11^{\mathrm{T}}$ was able to grow at $35-57{ }^{\circ} \mathrm{C}$, with optimum growth around $50{ }^{\circ} \mathrm{C}$. The $\mathrm{pH}$ range for growth was $\mathrm{pH}$ 5.9-8.7, with optimum growth at $\mathrm{pH}$ 7.6. The isolate grew optimally at $\mathrm{NaCl}$ concentrations of $0-0.3 \%(\mathrm{w} / \mathrm{v})$, and no growth was observed above $0.6 \% \mathrm{NaCl}$.
Hydrolysis of casein, starch (Manaia \& da Costa, 1991) and gelatin (Smibert \& Krieg, 1981) and degradation of arbutin, aesculin (Manaia \& da Costa, 1991), elastin, hide-powder azure and fibrin (Hudson et al., 1986) were tested by using Thermus medium. Strain AZM $34 \mathrm{c}^{1} 1^{\mathrm{T}}$ was positive for hydrolysis of starch and gelatin and for the degradation of hide-powder azure, but was negative for the other reactions. Additional enzyme activities were tested and identified by using the API ZYM system (bioMérieux) at $50{ }^{\circ} \mathrm{C}$; the strain showed positive reactions for several enzymes.

Respiratory quinones were extracted from cells of strain AZM $34 \mathrm{c} 11^{\mathrm{T}}$ by using the protocol described by Nakagawa \& Yamasato (1993) and analysed with an LCMS-QP 8000alpha spectrometer (Shimadzu). This respiratory quinone was menaquinone-8, which has been found in all described members of the phylum Deinococcus-Thermus. Cellular fatty acids of strain AZM $34 \mathrm{c} 11^{\mathrm{T}}$ grown at $50{ }^{\circ} \mathrm{C}$ were prepared by using the method of Sasser (1990) and were analysed with the MIDI microbial identification system (Microbial ID; Agilent Technologies); M. cerbereus NBRC $106473^{\mathrm{T}}, M$. granaticius NBRC $107808^{\mathrm{T}}$ and M. rufus NBRC $107809^{\mathrm{T}}$ were also analysed by using the same procedure. Strain AZM $34 \mathrm{c} 11^{\mathrm{T}}$ possessed mainly iso- and anteiso-branched fatty acids (see Supplementary Table S1, available in IJSEM Online); 2- and 3-hydroxy fatty acids were detected in very minor amounts. The polar lipids of strain AZM $34 \mathrm{c} 11^{\mathrm{T}}, M$. cerbereus NBRC $106473^{\mathrm{T}}$, M. granaticius NBRC $107808^{\mathrm{T}}$ and M. rufus NBRC $107809^{\mathrm{T}}$ were extracted and examined by two-dimensional TLC by using a previously described method (Hamada et al., 2010), and the patterns were visualized by spraying the TLC plates with $5 \%$ phosphomolybdic acid, Dittmer-Lester reagent (Dittmer \& Lester, 1964) and anisaldehyde. The polar lipid pattern of strain AZM34c1 $11^{\mathrm{T}}$ mainly comprised one phospholipid and one glycolipid, designated PL-2 and GL-1b, respectively (Nobre \& da Costa, 2001), as with the profiles of M. rufus NBRC $107809^{\mathrm{T}}$ and M. granaticius NBRC $107808^{\mathrm{T}}$, but in contrast to that of $M$. cerbereus NBRC $106473^{\mathrm{T}}$, which contained two glycolipids (not shown). The genomic DNA G $+\mathrm{C}$ content was determined by HPLC with a Shodex ODS pack F-411 (Showa Denko K.K.), after an initial nuclease P1 treatment by using a DNA-GC kit (Yamasa Shoyu) followed by alkaline phosphatase treatment (Kamagata \& Mikami, 1991). The DNA G $+C$ content of strain AZM34c11 ${ }^{\mathrm{T}}$ was $63.4 \mathrm{~mol} \%$.

The almost-complete 16S rRNA gene sequence of strain AZM $34 \mathrm{c} 11^{\mathrm{T}}$ was determined by using a previously reported procedure (Hattori et al., 2000). After alignment with the ARB program version 5.2 (Ludwig et al., 2004) and the dataset version ssu_jan04.arb, the aligned data were extracted by using the ARB default filter (deinococcus_thermus_rr5_ dec04; 1369 positions) and phylogenetic trees were reconstructed with the neighbour-joining (NJ) method via the CLUSTAL X program version 1.83 (Saitou \& Nei, 1987; Thompson et al., 1997) and with the maximum-likelihood (ML) method via the MOLPHY program version $2.3 \mathrm{~b} 3$ 
Table 1. Differential characteristics between strain $A Z M 34 c 11^{\top}$ and recognized Meiothermus species

Taxa: 1, strain AZM34c11 ${ }^{\mathrm{T}}$; 2, M. ruber; 3, M. silvanus; 4, M. chliarophilus; 5, M. cerbereus; 6, M. taiwanensis; 7, M. timidus; 8, M. cateniformans; 9, M. rufus; 10, M. granaticius. Data for recognized Meiothermus species were from Nobre \& da Costa (2001), Tenreiro et al. (1995), Chung et al. (1997), Chen et al. (2002), Pires et al. (2005), Zhang et al. (2010) and Albuquerque et al. (2009, 2010). All taxa were positive for oxidase and utilization of D-glucose and D-fructose. \pm , Variable; ND, no data available.

\begin{tabular}{|c|c|c|c|c|c|c|c|c|c|c|}
\hline Characteristic & 1 & 2 & 3 & 4 & 5 & 6 & 7 & 8 & 9 & 10 \\
\hline Pigmentation & Red & Red & Red & Yellow & Red & Red & Yellow & Red & Red & Red \\
\hline Optimum growth temperature $\left({ }^{\circ} \mathrm{C}\right)$ & 50 & 60 & 55 & 50 & 55 & $55-60$ & $55-60$ & $55-60$ & $55-60$ & $45-50$ \\
\hline Growth with $1 \% \mathrm{NaCl}$ & - & + & - & + & + & + & + & $\mathrm{ND}$ & - & - \\
\hline Reduction of nitrate to nitrite & + & - & + & + & - & - & + & \pm & + & + \\
\hline Genomic DNA G $+C$ content $(\mathrm{mol} \%)^{*}$ & $63.4^{a}$ & $66.0^{b}$ & $63.6^{a}$ & $69.9^{a}$ & $60.9^{a}$ & $61.9^{a}$ & $65.1^{a}$ & $60.8-61.5^{b}$ & $64.1^{a}$ & $63.5^{a}$ \\
\hline $\begin{array}{l}\text { Requirement for reduced sulfur compounds } \\
\text { for growth in liquid medium }\end{array}$ & - & - & \pm & - & + & $\mathrm{ND}$ & $\mathrm{ND}$ & ND & $\mathrm{ND}$ & $\mathrm{ND}$ \\
\hline \multicolumn{11}{|l|}{ Enzyme activity } \\
\hline Catalase & - & + & - & - & - & + & + & + & + & + \\
\hline$\alpha$-Galactosidase & - & + & - & + & + & + & ND & ND & - & + \\
\hline \multicolumn{11}{|l|}{ Hydrolysis of: } \\
\hline Elastin & - & + & + & + & + & + & + & ND & + & ND \\
\hline Fibrin & - & + & - & + & + & + & ND & ND & ND & $\mathrm{ND}$ \\
\hline Starch & + & - & + & + & - & - & + & - & + & + \\
\hline Casein & - & + & + & + & + & + & + & - & + & + \\
\hline Gelatin & + & + & + & + & + & + & $\mathrm{ND}$ & + & + & + \\
\hline Arbutin & - & + & + & + & + & ND & $\mathrm{ND}$ & ND & + & + \\
\hline Aesculin & - & + & ND & + & + & + & $\mathrm{ND}$ & + & + & + \\
\hline \multicolumn{11}{|l|}{ Utilization of growth substrate } \\
\hline Lactose & + & + & + & + & + & + & $\mathrm{ND}$ & - & + & + \\
\hline Trehalose & + & + & - & + & + & - & + & - & + & + \\
\hline Sucrose & + & + & - & + & + & + & + & - & + & + \\
\hline Cellobiose & + & + & - & + & + & + & + & + & + & + \\
\hline Raffinose & - & + & - & + & - & + & + & - & - & - \\
\hline D-Arabinose & - & - & - & - & - & + & + & - & + & - \\
\hline L-Rhamnose & - & - & - & - & - & + & - & - & - & - \\
\hline D-Xylose & + & + & + & + & - & + & + & + & + & + \\
\hline Ribitol & - & - & + & - & - & + & - & - & - & - \\
\hline D-Mannitol & - & + & + & + & - & + & + & + & + & + \\
\hline D-Sorbitol & - & + & + & + & - & + & + & + & + & - \\
\hline Glycerol & + & + & - & + & - & - & - & - & - & - \\
\hline Pyruvate & + & - & + & + & + & + & + & + & + & - \\
\hline Succinate & - & + & - & - & - & + & + & - & + & + \\
\hline Malate & - & + & + & - & - & - & + & - & + & + \\
\hline myo-Inositol & - & + & - & - & - & + & - & - & - & + \\
\hline L-Asparagine & + & + & + & + & - & + & + & + & + & - \\
\hline L-Glutamate & + & + & + & + & + & + & ND & + & + & - \\
\hline L-Glutamine & - & + & + & + & - & + & + & - & + & + \\
\hline L-Serine & - & + & + & + & - & - & + & + & - & - \\
\hline L-Proline & - & + & + & + & + & + & + & + & - & - \\
\hline L-Arginine & - & + & + & + & - & + & + & + & + & - \\
\hline
\end{tabular}

${ }^{\star}$ Determined by HPLC $(a)$ or $T_{\mathrm{m}}(b)$.

(Adachi \& Hasegawa, 1995; Hasegawa et al., 1985; Mori et al., 2008b). The sequence determined indicated that strain AZM $34 \mathrm{C}_{11} 1^{\mathrm{T}}$ belonged to the genus Meiothermus in the family Thermaceae. The NJ tree constructed on the basis of the 16S rRNA gene sequence of the new isolate and those of related strains is shown in Fig. 1. The result obtained with the
ML method was similar to that obtained with the NJ method (not shown). Levels of 16S rRNA gene sequence similarity calculated by the CLUSTAL $\mathrm{x}$ program between strain AZM34 $11^{\mathrm{T}}$ and the type strains of recognized Meiothermus species were as follows: M. ruber, $93.7 \%$; M. silvanus, $88.4 \%$; M. chliarophilus, $88.2 \%$; M. cerbereus, $94.8 \%$; 


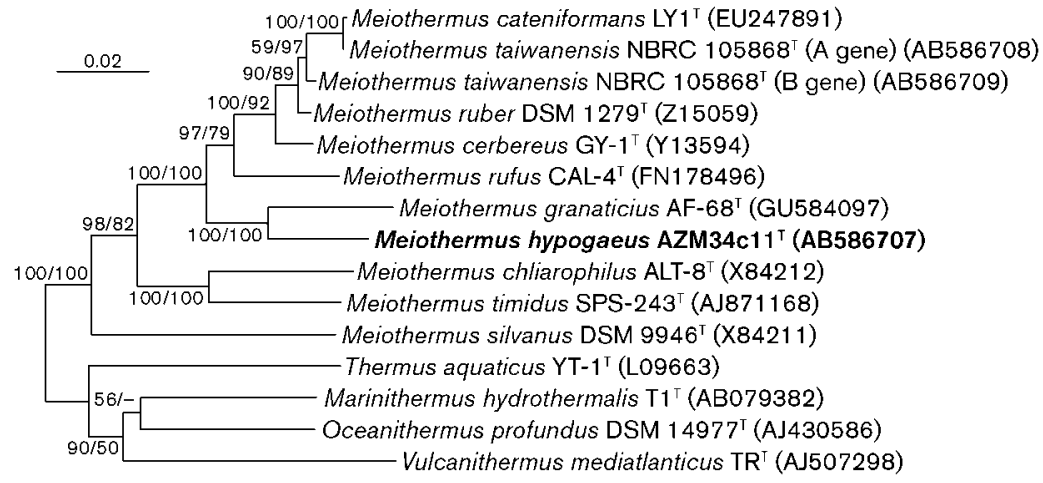

Fig. 1. NJ phylogenetic tree based on $16 S$
rRNA gene sequences of strain $A Z M 34 c 11^{\top}$
and relatives. Bootstrap percentages $\geqslant 50 \%$
are indicated at branch points (NJ/ML); -,
$<50 \%$. GenBank/EMBL/DDBJ accession num-
bers are shown in parentheses. Bar, 0.02 sub-
stitutions per nucleotide position.

Meiothermus taiwanensis, 93.2 and $93.7 \%$ (see below); $M$. timidus, 90.9\%; Meiothermus cateniformans, 93.2\%; $M$. rufus, $92.9 \%$; and M. granaticius, $94.8 \%$.

The 16S rRNA gene sequence of $M$. taiwanensis NBRC $105868^{\mathrm{T}}$ was also determined by direct sequencing as described above, but a single sequence could not be determined and some positions were indeterminate. Therefore, PCR products retrieved from single colonies of $M$. taiwanensis NBRC $105868^{\mathrm{T}}$ were cloned by using the TOPO TA Cloning kit (Invitrogen), and the sequences were then determined. As a result, two different 16S rRNA gene sequences were obtained for $M$. taiwanensis NBRC $105868^{\mathrm{T}}$ and the sequence similarity between them was $98.9 \%$. The phylogenetic positions of the two sequences, $\mathrm{A}$ and $\mathrm{B}$, in the genus Meiothermus are shown in Fig. 1. Both the sequences obtained in our study differed in several nucleotides from the previously registered sequence (AF418001) and, phylogenetically, they formed a complex relationship with $M$. ruber and $M$. cateniformans. The high levels of DNA-DNA relatedness among the type strains of the three species (Zhang et al., 2010) support our results. However, similar results were not obtained with the $16 \mathrm{~S}$ rRNA gene sequence of $M$. ruber NBRC $106122^{\mathrm{T}}$ in the present study (not shown).

The phylogenetic analysis performed based on 16S rRNA gene sequences indicated that strain $\mathrm{AZM} 34 \mathrm{c} 11^{\mathrm{T}}$ belonged to the genus Meiothermus. The 16S rRNA gene sequence of strain AZM34c1 $11^{\mathrm{T}}$ was different from those of all recognized species of the genus Meiothermus, and levels of similarity between this strain and the type strains of Meiothermus species were less than 95\%. Differential characteristics between strain AZM34c11 ${ }^{\mathrm{T}}$ and recognized Meiothermus species are summarized in Table 1. Strain AZM34c1 $11^{\mathrm{T}}$ exhibited several phenotypic and chemotaxonomic characters such as pigmentation, optimum growth temperature, DNA G $+\mathrm{C}$ content and respiratory quinone content that are typical of the genus Meiothermus. However, the characteristics did not match completely with those of recognized Meiothermus species. In particular, the utilization of sugars and amino acids as single carbon and energy sources was clearly different. The cellular fatty acid composition of strain AZM $34 \mathrm{c} 11^{\mathrm{T}}$ was similar to those of recognized Meiothermus species: iso-branched and anteiso-branched fatty acids were the predominant components (Supplementary Table S1). However, the amount of hydroxy fatty acids in strain AZM34c1 $1^{\mathrm{T}}$ was very low, which is a feature seen only in $M$. rufus and $M$. granaticius in the entire genus Meiothermus (Albuquerque et al., 2009, 2010). In addition, iso- $\mathrm{C}_{16: 0}$ was present in larger quantities in strain $\mathrm{AZM} 34 \mathrm{c} 11^{\mathrm{T}}$ than in recognized species of the genus Meiothermus. These phenotypic differences support the phylogenetically distinct position of strain AZM $34 \mathrm{c} 11^{\mathrm{T}}$ in the genus Meiothermus. Based on the data presented above, we suggest that strain AZM34c1 $1^{\mathrm{T}}$ represents a novel species of the genus Meiothermus, for which the name Meiothermus hypogaeus sp. nov. is proposed.

As reported by some researchers (Nobre \& da Costa, 2001; Nobre et al., 1996; Pires et al., 2005), phylogenetic analysis based on 16S rRNA gene sequences indicated that $M$. silvanus, $M$. chliarophilus and M. timidus were distant from the other Meiothermus species at a high replicate/resampling value (Fig. 1) and levels of sequence similarity between the type strains of the three species and other Meiothermus species were less than $91.5 \%$. Although it may be reasonable to erect a new genus for the three species based on phylogenetic analysis, this is not supported by phenotypic and chemotaxonomic characteristics. The isolation of additional novel representatives related to $M$. silvanus, $M$. chliarophilus and $M$. timidus will be important in this regard.

\section{Description of Meiothermus hypogaeus sp. nov.}

Meiothermus hypogaeus (hy.po.gae'us. L. masc. adj. hypogaeus underground, living under the ground).

Cells are rod-shaped $(0.4 \mu \mathrm{m}$ wide and 1.7-10.0 $\mu \mathrm{m}$ long), red-pigmented, non-motile and non-sporulating. Gram reaction is negative. Catalase-negative and oxidase-positive. Nitrate is reduced to nitrite. Positive for hydrolysis of starch and gelatin and degradation of hide-powder azure. Negative for hydrolysis of casein and degradation of arbutin, aesculin, elastin and fibrin. API ZYM tests were positive for alkaline phosphatase, esterase (C4), esterase lipase (C8), $\alpha$-chymotrypsin, acid phosphatase, naphtholAS-BI-phosphohydrolase, $\beta$-galactosidase, $\alpha$-glucosidase and $\beta$-glucosidase, but negative for lipase (C14), leucine 
arylamidase, valine arylamidase, cystine arylamidase, trypsin, $\alpha$-galactosidase, $\beta$-glucuronidase, $N$-acetyl- $\beta$-glucosaminidase, $\alpha$-mannosidase and $\alpha$-fucosidase. Cells are aerobic and chemoheterotrophic, requiring yeast extract for growth. Sulfur compounds are not required for growth in liquid medium. Utilizes D-glucose, D-fructose, D-mannose, Dgalactose, melibiose, maltose, lactose, trehalose, sucrose, cellobiose, D-xylose, glycerol, pyruvate, L-asparagine and L-glutamate as carbon and energy sources, but not raffinose, D-arabinose, L-rhamnose, ribitol, D-mannitol, D-sorbitol, citrate, succinate, malate, myo-inositol, L-glutamine, Lserine, L-proline or L-arginine. Grows at $35-57{ }^{\circ} \mathrm{C}$; optimum growth at $50{ }^{\circ} \mathrm{C}$. The $\mathrm{pH}$ range for growth is 5.9-8.7, with optimum growth at $\mathrm{pH} 7.6$. Grows optimally with $0-0.3 \%$ (w/v) NaCl; no growth occurs with more than $0.6 \%(\mathrm{w} / \mathrm{v})$ $\mathrm{NaCl}$. Menaquinone- 8 is the major respiratory quinone. The major cellular fatty acids are iso- $\mathrm{C}_{15: 0}$ and iso- $\mathrm{C}_{16: 0}$. The major polar lipids are PL-2 and GL-1b. The genomic DNA $\mathrm{G}+\mathrm{C}$ content of the type strain is $63.4 \mathrm{~mol} \%$.

The type strain, AZM34c11 $1^{\mathrm{T}}\left(=\mathrm{NBRC} 106114^{\mathrm{T}}=\mathrm{DSM}\right.$ $23238^{\mathrm{T}}$ ), was isolated from hot-spring water collected from the bottom of a 1000 m-deep drilled well in HakubaHimekawa, Nagano Prefecture, Japan.

\section{Acknowledgements}

We thank Mr Haruhiko Sejima of Happoonekaihatsu and staff of Hakuba Highland Hotel for collecting the hot spring sample. We thank Kuniko Shimamura, Shinobu Iwasaki, Motoyuki Ohuchi, Yuki Muramatsu, Shinya Ninomiya and Yuumi Ishida for technical support.

\section{References}

Adachi, J. \& Hasegawa, M. (1995). Improved dating of the human/ chimpanzee separation in the mitochondrial DNA tree: heterogeneity among amino acid sites. J Mol Evol 40, 622-628.

Albuquerque, L., Ferreira, C., Tomaz, D., Tiago, I., Veríssimo, A., da Costa, M. S. \& Nobre, M. F. (2009). Meiothermus rufus sp. nov., a new slightly thermophilic red-pigmented species and emended description of the genus Meiothermus. Syst Appl Microbiol 32, 306-313.

Albuquerque, L., Rainey, F. A., Nobre, M. F. \& da Costa, M. S. (2010). Meiothermus granaticius sp. nov., a new slightly thermophilic redpigmented species from the Azores. Syst Appl Microbiol 33, 243-246.

Castenholz, R. W. (1969). Thermophilic blue-green algae and the thermal environment. Bacteriol Rev 33, 476-504.

Chen, M. Y., Lin, G. H., Lin, Y. T. \& Tsay, S. S. (2002). Meiothermus taiwanensis sp. nov., a novel filamentous, thermophilic species isolated in Taiwan. Int J Syst Evol Microbiol 52, 1647-1654.

Chung, A. P., Rainey, F., Nobre, M. F., Burghardt, J. \& da Costa, M. S. (1997). Meiothermus cerbereus sp. nov., a new slightly thermophilic species with high levels of 3-hydroxy fatty acids. Int J Syst Bacteriol 47, $1225-1230$.

Dittmer, J. C. \& Lester, R. L. (1964). A simple, specific spray for the detection of phospholipids on thin-layer chromatograms. J Lipid Res 15, 126-127.

Dobrogosz, W. J. (1981). Enzymatic activity. In Manual of Methods for General Bacteriology, pp. 365-392. Edited by P. Gerhardt, R. G. E. Murray,
R. N. Costilow, E. W. Nester, W. A. Wood, N. R. Krieg \& G. B. Phillips. Washington, DC: American Society for Microbiology.

Ekman, J., Kosonen, M., Jokela, S., Kolari, M., Korhonen, P. \& Salkinoja-Salonen, M. (2007). Detection and quantitation of colored deposit-forming Meiothermus spp. in paper industry processes and end products. J Ind Microbiol Biotechnol 34, 203-211.

Hamada, M., lino, T., Iwami, T., Harayama, S., Tamura, T. \& Suzuki, K. (2010). Mobilicoccus pelagius gen. nov., sp. nov. and Piscicoccus intestinalis gen. nov., sp. nov., two new members of the family Dermatophilaceae, and reclassification of Dermatophilus chelonae (Masters et al. 1995) as Austwickia chelonae gen. nov., comb. nov. J Gen Appl Microbiol 56, 427-436.

Hasegawa, M., Kishino, H. \& Yano, T. A. (1985). Dating of the human-ape splitting by a molecular clock of mitochondrial DNA. J Mol Evol 22, 160-174.

Hattori, S., Kamagata, Y., Hanada, S. \& Shoun, H. (2000). Thermacetogenium phaeum gen. nov., sp. nov., a strictly anaerobic, thermophilic, syntrophic acetate-oxidizing bacterium. Int J Syst Evol Microbiol 50, 1601-1609.

Hudson, J. A., Morgan, H. W. \& Daniel, R. M. (1986). A numerical classification of some Thermus isolates. J Gen Microbiol 132, 531-540.

Kamagata, Y. \& Mikami, E. (1991). Isolation and characterization of a novel thermophilic Methanosaeta strain. Int J Syst Bacteriol 41, 191196.

Loginova, L. G., Egorova, L. A., Golovacheva, R. S. \& Seregina, L. M. (1984). Thermus ruber sp. nov., nom. rev. Int J Syst Bacteriol 34, 498499.

Ludwig, W., Strunk, O., Westram, R., Richter, L., Meier, H., Yadhukumar, Buchner, A., Lai, T., Steppi, S. \& other authors (2004). ARB: a software environment for sequence data. Nucleic Acids Res 32, 1363-1371.

Manaia, C. M. \& da Costa, M. S. (1991). Characterization of halotolerant Thermus isolates from shallow marine hot springs on S. Miguel, Azores. J Gen Microbiol 137, 2643-2648.

Mori, K., Maruyama, A., Urabe, T., Suzuki, K. \& Hanada, S. (2008a). Archaeoglobus infectus sp. nov., a novel thermophilic, chemolithoheterotrophic archaeon isolated from a deep-sea rock collected at Suiyo Seamount, Izu-Bonin Arc, western Pacific Ocean. Int J Syst Evol Microbiol 58, 810-816.

Mori, K., Sunamura, M., Yanagawa, K., Ishibashi, J., Miyoshi, Y., lino, T., Suzuki, K. \& Urabe, T. (2008b). First cultivation and ecological investigation of a bacterium affiliated with the candidate phylum OP5 from hot springs. Appl Environ Microbiol 74, 6223-6229.

Nakagawa, Y. \& Yamasato, K. (1993). Phylogenetic diversity of the genus Cytophaga revealed by $16 \mathrm{~S}$ rRNA sequencing and menaquinone analysis. J Gen Microbiol 139, 1155-1161.

Nobre, M. F. \& da Costa, M. S. (2001). Genus II. Meiothermus Nobre, Trüper and da Costa, 1996b, 605 ${ }^{\mathrm{VP}}$. In Bergey's Manual of Systematic Bacteriology, 2nd edn, vol. 1, pp. 414-420. Edited by D. R. Boone, R. W. Castenholtz \& G. M. Garrity. New York: Springer.

Nobre, M. F., Trüper, H. G. \& da Costa, M. S. (1996). Transfer of Thermus ruber (Loginova et al. 1984), Thermus silvanus (Tenreiro et al. 1995), and Thermus chliarophilus (Tenreiro et al. 1995) to Meiothermus gen. nov. as Meiothermus ruber comb. nov., Meiothermus silvanus comb. nov., and Meiothermus chliarophilus comb. nov., respectively, and emendation of the genus Thermus. Int J Syst Bacteriol 46, 604-606.

Pires, A. L., Albuquerque, L., Tiago, I., Nobre, M. F., Empadinhas, N., Veríssimo, A. \& da Costa, M. S. (2005). Meiothermus timidus sp. nov., a new slightly thermophilic yellow-pigmented species. FEMS Microbiol Lett 245, 39-45.

Saitou, N. \& Nei, M. (1987). The neighbor-joining method: a new method for reconstructing phylogenetic trees. Mol Biol Evol 4, 406-425. 
Sasser, M. (1990). Identification of bacteria by gas chromatography of cellular fatty acids, MIDI Technical Note 101. Newark, DE: MIDI Inc.

Smibert, R. M. \& Krieg, N. R. (1981). General characterization. In Manual of Methods for General Bacteriology, pp. 409-443. Edited by P. Gerhardt, R. G. E. Murray, R. N. Costilow, E. W. Nester, W. A. Wood, N. R. Krieg \& G. B. Phillips. Washington, DC: American Society for Microbiology.

Tamaki, H., Hanada, S., Kamagata, Y., Nakamura, K., Nomura, N., Nakano, K. \& Matsumura, M. (2003). Flavobacterium limicola sp. nov., a psychrophilic, organic-polymer-degrading bacterium isolated from freshwater sediments. Int J Syst Evol Microbiol 53, 519-526.
Tenreiro, S., Nobre, M. F. \& da Costa, M. S. (1995). Thermus silvanus sp. nov. and Thermus chliarophilus sp. nov., two new species related to Thermus ruber but with lower growth temperatures. Int J Syst Bacteriol 45, 633-639.

Thompson, J. D., Gibson, T. J., Plewniak, F., Jeanmougin, F. \& Higgins, D. G. (1997). The CLUSTAL_X windows interface: flexible strategies for multiple sequence alignment aided by quality analysis tools. Nucleic Acids Res 25, 4876-4882.

Zhang, X. O., Zhang, W. J., Wei, B. P., Xu, X. W., Zhu, X. F. \& Wu, M. (2010). Meiothermus cateniformans sp. nov., a slightly thermophilic species from north-eastern China. Int J Syst Evol Microbiol 60, 840-844. 